\title{
Sampling methods for titica vine (Heteropsis spp.) inventory in a tropical forest
}

\author{
Carine Klauberg $^{1,2} \cdot$ Edson Vidal $^{1} \cdot$ Carlos Alberto Silva $^{3} \cdot$ Michelliny de M. Bentes $^{4}$. \\ Andrew Thomas Hudak ${ }^{2}$
}

Received: 9 November 2015 / Accepted: 26 May 2016 / Published online: 7 June 2016

(C) INRA and Springer-Verlag France 2016

\begin{abstract}
- Key message Titica vine provides useful raw fiber material. Using sampling schemes that reduce sampling error can provide direction for sustainable forest management of this vine. Sampling systematically with rectangular plots $(10 \times 25 \mathrm{~m})$ promoted lower error and greater accuracy in the inventory of titica vines in tropical rainforest - Context The titica vine (Heteropsis spp.) is an important raw material for native communities located in the Amazon tropical rainforest. However, variability and spatial distribution of
\end{abstract}

\section{Handling Editor: Erwin Dreyer}

Contribution of the co-authors Carine Klauberg: designing the experiment, collecting data, running the data analysis, and writing the paper.

Edson Vidal: supervising the work, coordinating the research project, and advising in data analysis.

Carlos Alberto Silva: designing the experiment, running the data analysis, and advising in data analysis.

Michelliny de M. Bentes: advising in data analysis.

Andrew Thomas Hudak: advising in data analysis, writing, and revising of the paper.

\section{Carine Klauberg}

carine klauberg@hotmail.com

1 Department of Forest Sciences, Escola Superior de Agricultura "Luiz de Queiroz", University of São Paulo, Av. Pádua Dias, 11 Cx. P 09, CEP 13418-900 Piracicaba, SP, Brazil

2 Present address: USDA Forest Service Rocky Mountain Research Station, Forestry Sciences Laboratory, 1221 South Main Street, Moscow, ID 83843, USA

3 Department of Natural Resources and Society, University of Idaho, 708 South Deakin Street, Moscow, ID 83844, USA

4 Embrapa Amazônia Oriental (CPATU), Empresa Brasileira de Pesquisa Agropecuária (Embrapa), Trav. Dr. Enéas Pinheiro s $/ \mathrm{n}^{\circ}$, Caixa Postal, 48, CEP 66095-100 Belém, PA, Brazil this species are some factors that hinder the assessment of accurate productivity prediction, and thus, inventory methods for management plan must be defined.

- Aims The aim of this study was to develop and compare accuracy of different sampling approaches for the inventory of titica vines (roots ha ${ }^{-1}$ ) using simulations based on field data. - Methods Eighty-eight treatments were defined by the combination of the process (random or systematic), sampling intensity $(5,10,15$, and $20 \%$ of 18 ha), plot size ( 250 to $3000 \mathrm{~m}^{2}$ ) and shapes (square, rectangle, and transect). Production estimate, sampling error, and relative efficiency were used to compare treatments with each other and with the reference inventory.

- Results The mean production estimates for the random and systematic processes were 570 and 597 vine roots ha ${ }^{-1}$, while the reference estimate was 500 vine roots ha ${ }^{-1}$. Among of the treatments evaluated, only $5.8 \%$ of them provided a sampling error less than $15 \%$.

- Conclusion The sampling procedure that combines systematic or random process, plots sizes of 250 or $300 \mathrm{~m}^{2}$ and sampling intensity greater than $15 \%$ was the most efficient for inventory of titica vine in tropical forests.

Keywords Heteropsis $\cdot$ Inventory $\cdot$ Non-timber forest product - Simulation $\cdot$ Araceae $\cdot$ Hemiepiphyte $\cdot$ Random plot $\cdot$ Sampling scheme $\cdot$ Systematic plot $\cdot$ Tropical forest

\section{Introduction}

The Brazilian biodiversity is a rich repository of multiple use species of plants. Among them, many species of vines are particularly appreciated by rural inhabitants who exploit the roots and fibers for commercial purposes. Belonging to the genus Heteropsis (Araceae), this hemiepiphyte grows 
commonly throughout Brazil, mostly in natural forests of the Amazon Basin and Atlantic Forest regions (Bentes-Gama et al. 2013; Soares et al. 2009; Plowden et al. 2003). The vine is popularly known by "titicão" or titica vine (Shanley and Medina 2005). Its natural occurrence seems to indicate a healthy forest because more light penetration through the forest canopy to the soil inhibits the occurrence of the species (Shanley and Medina 2005; Knab-Vispo et al. 2003).

Suspended titica vine roots, commonly called "legs", provide a valuable raw material that is a resistant and workable fiber (Shanley and Medina 2005). The main uses of this raw material are for furniture making, crafts (baskets, paneiros), brooms, moorings, and medicinal products (Durigan and Castilho 2004; Oliveira et al. 2006; y Paz et al. 1995). Currently, titica vine fibers are usually extracted through predatory exploitation, which can cause local extinction of the species where it naturally occurs (Scipioni et al. 2012). In regions where management of titica vine is employed, commercial collection of only $50 \%$ of the total number of ripe roots is allowed (Durigan and Castilho 2004; Hoffman 1997). This limitation reduces stress on plants and promotes the sustainability of the species in its naturally occurring habitats.

There are generally few studies demonstrating the sustainability of harvesting titica vine and other non-timber forest products (NTFPs); more specifically, no literature is available on harvest effects on the structure of the individuals, such as emergence of roots, flowers and fruits, or the impact of titica vine harvest on the ecosystem (Belcher and Schreckenberg 2007; Boot 1997).

Studies focusing on the type of sampling for inventory of NTFPs are also scarce, and only a few studies propose specific inventory methodologies for non-timber species (Bruzinga et al. 2014; Evans and Viengkham 2001; Kleinn et al. 1996; Stockdale and Wright 1996, and Tonini 2013). Studies sampling approaches for inventory are typically focused on analysis and ecological processes in the form of phenological or regeneration evaluations (D'Eça-Neves and Morellato 2004; Gama et al. 2001) and/or the stock of wood in natural forests (Cavalcanti et al. 2011; Piqué et al. 2011) and plantations (Druszcz et al. 2010; Fick 2011).

Productivity of the trees is easiest to evaluate given the availability of existing forest inventory protocols that quantify wood products using prediction equations based on tree size (typically bole diameter) (Wong et al. 2000). On the other hand, the NTFP productivity assessment is problematic because of confounding issues of scale, spatial distribution, rarity, seasonality, botanical identification, and detectability (Wong et al. 2000). The authors also highlight the absence of known relationship between productivity and the characteristics of the plant, which may present a high variability causing serious difficulties for inventory purpose.

Traditional sampling techniques for timber inventory cannot be easily adapted for NTFPs because they tend to be inefficient (Wong et al. 2000). Therefore, studies of vines are needed that assess proper sizes and shapes of plots and types of sampling — random or systematic - that may offer a higher accuracy in production estimates (Gama et al. 2001). This study is a pioneer initiative to propose a sample scheme for inventorying titica vine for NTFP management and planning.

The aim of the study was to compare approaches for titica vine inventory (roots $\mathrm{ha}^{1}$ ) using simulations based on field data, in order to (1) evaluate the accuracy of production estimates of titica vines by simulation and analysis of two different sampling procedures; the best sampling intensity, as well as the ideal size and shape of the plot; and (2) propose an outline for efficiently sampling titica vines in the forests of the Amazon Basin.

\section{Material and methods}

\subsection{Study area}

The study area is located in the state of Pará, municipality of Paragominas, between $3^{\circ} 35^{\prime}$ and $3^{\circ} 45^{\prime}$ south latitude and $48^{\circ}$ $15^{\prime}$ and $48^{\circ} 25^{\prime}$ west longitude. It is part of the forest area in the Center of Management "Roberto Bauch" and is administered by the Tropical Forest Institute (IFT). It is approximately 5000 ha in area and is used for demonstrating and training on how to manage forests to reduce environmental and economic impacts in the Amazon.

The forest is predominantly classified as a dense ombrophilous forest of "terra firme" (IBGE 2004). The local topography is moderately wavy with soil types that are predominately dystrophic yellow latosol (IBGE 2001). The climate is typically humid, with an average annual temperature of $25^{\circ} \mathrm{C}$ and an average annual precipitation of $2200 \mathrm{~mm}$, which is concentrated between the months of January and June (Alvares et al. 2013).

\subsection{Data collection}

The database for this study was obtained through an inventory of titica vine in 12 randomly distributed plots, each with a size of $100 \mathrm{~m} \times 150 \mathrm{~m}$, totaling 18 ha of sample area (reference inventory). Within plots, all individual trees with DBH $\geq 10 \mathrm{~cm}$ that included titica vines were measured and mapped accordingly to the Amazon non-timber forest products network of EMBRAPA (Kamukaia). Tree diameter at breast height (DBH, $1.30 \mathrm{~m}$ ) was measured using a diameter tape; species identification was based on the experience of a field assistant ("parabotânico") employed by IFT. The number of "legs" (roots issued by the plant mother) on titica vines was quantified for each host (Shanley and Medina 2005). Whether the vine roots were mature, immature, commercial, noncommercial, or dead was not registered. 


\subsection{Simulation and data processing}

For the sampling process simulation (random and systematic), a map representing the spatial distribution of titica host trees measured in the field was drawn up through the program ArcGIS 10.1 ® based on the 12 plots surveyed. For each spatialized plot, the Sampling Tools utility within Hawth's Analysis was employed to create a grid with subplots of previously established dimensions (Table 1). Using the Intersect tool in ArcGIS 10.1 ®, the grids were linked with the inventory data previously spatialized, and 11 files were extracted with the inventory information associated with the number of plots for each of the 12 plots surveyed.

For the simulations of the random sampling process, a random sample of subplots from the grid was selected using $\mathrm{R}$ 3.0.2 (R Development Core Team 2015). For the systematic sampling of a single stage, simulations were made directly in the program ArcGIS 10.1 ®. A randomized point was created for each simulation on the grid, and from this point, the subplots that were present on the grid were selected in all directions, using the distance of $1 k$, where $k$ corresponds to a sampling unit.

In both sampling procedures, 11 types of plots varying in shape (rectangular or square) and size (area) were used. The number of plots used in each simulation was determined through sampling intensities of 5, 10, 15 and $20 \%$ from the total area of 18 ha (Table 1), i.e., the total area percentage of the population that was sampled.

The combination of the sampling process as well as the size and shape of the plots provided 88 different types of simulations, which were called treatments. For each treatment, 30 replications were applied to provide sufficient information

Table 1 Number of plots tested by sampling procedure (simple random and systematic single stage) in accordance with the plot area, dimensions, and sampling intensity

\begin{tabular}{|c|c|c|c|c|c|c|}
\hline \multirow[t]{2}{*}{ No. } & \multicolumn{2}{|l|}{ Plot } & \multicolumn{4}{|c|}{ Sampling intensity } \\
\hline & Area $\left(\mathrm{m}^{2}\right)$ & Dimensions & $5 \%$ & $10 \%$ & $15 \%$ & $20 \%$ \\
\hline 1 & 250 & $10 \times 25$ & 36 & 72 & 108 & 144 \\
\hline 2 & 300 & $15 \times 20$ & 30 & 60 & 90 & 120 \\
\hline 3 & 300 & $10 \times 30$ & 30 & 60 & 90 & 120 \\
\hline 4 & 500 & $20 \times 25$ & 18 & 36 & 54 & 72 \\
\hline 5 & 600 & $40 \times 15$ & 15 & 30 & 45 & 60 \\
\hline 6 & 600 & $20 \times 30$ & 15 & 30 & 45 & 60 \\
\hline 7 & 900 & $30 \times 30$ & 10 & 20 & 20 & 40 \\
\hline 8 & 900 & $6 \times 150$ & 10 & 20 & 30 & 40 \\
\hline 9 & 1000 & $10 \times 100$ & 9 & 18 & 27 & 36 \\
\hline 10 & 1500 & $10 \times 150$ & 6 & 12 & 18 & 24 \\
\hline 11 & 3000 & $20 \times 150$ & 3 & 6 & 9 & 12 \\
\hline
\end{tabular}

for the statistical analyses. In total, we obtained 2640 plots, 1320 for each sampling procedure.

\subsection{Statistical analysis of the data}

The production of titica vine (vine roots $\mathrm{ha}^{-1}$ ) for each treatment was obtained after all simulations, and statistical analyses were performed to compare the estimates of production from the treatments to the reference inventory. For normally distributed data, ANOVA with Bonferroni tests $(\alpha=0.05)$ (Zar 1999 ) were performed to test for differences among production estimates between the treatments and the reference inventory. Applied statistics included variance $\left(\mathrm{s}^{2}\right)$; standard deviation (s); standard error of the mean $\left(\mathrm{S}_{\overline{\mathrm{x}}}\right)$ for infinite populations, for simple random sampling; and standard error of the mean for systematic sampling $\left(\mathrm{S}_{\overline{\mathrm{x}} \mathrm{s}}\right)$ (Péllico Netto and Brena 1997; Zar 1999).

To compare the performance among different sampling groups in relation to the reference inventory, the estimation of production per hectare was used in addition to the sampling error (Péllico Netto and Brena 1997) (Eq. 11) and the method of relative efficiency (Husch et al. 1972) (Eq. 1).

$E=\left(\frac{S_{\bar{x}}^{*} t}{\bar{x}}\right) * 100$

Where $t=$ Student's $t$ distribution of the $95 \%$ probability with $n-1$ degrees of freedom; $S_{\bar{x}}=$ standard error of the mean; and $\bar{x}=$ the arithmetic mean of the variable taken for comparison. Smaller sampling error shows higher accuracy of the inventory (Péllico Netto and Brena 1997). In tropical forests, the wide heterogeneity of species, complex spatial distributions of species and large number of rare species are factors that can cause high sampling errors (Ubialli et al. 2009). Comparatively, for timber management, the sampling error allowed, according to IBAMA, is $10 \%$ (Cavalcanti et al. 2011), and the maximum error allowed in diagnostic inventory of Clusia spp. and Heteropsis spp., in accordance with Resolution COEMA no. 013/2009 of the state of Amapá, is 20 \% (Amapá 2015). Since NTFP-type vines show high variability and seasonality of production, and because we were trying to evaluate sampling methods that resulted in a higher level of accuracy, the maximum value of the sample error was set at $15 \%$.

$e=\frac{\left(s_{\bar{x} 1}\right)^{2} * t_{1}}{\left(s_{\bar{x} 2}\right)^{2} * t_{2}} * 100$

Where $s_{\bar{x} 1}=$ the standard error $(\%)$ of the reference treatment; $s_{\bar{x} 2}=$ the standard error (\%) of the treatment to be compared with the reference; $t_{1}=$ the cost of inventory (installation 
of plots and measurements) in hours or monetary cost for the reference treatment; and $t_{2}=$ the cost for the treatment to be compared with the reference. If $e=100$, then the tested treatment is $100 \%$ efficient compared to the reference treatment. The relative efficiency ( $\mathrm{e} \%$ ) was computed just for the treatments with sampling error less than or equal to $15 \%$, where the reference treatment was the treatment with the smaller sampling error $(\mathrm{E} \%)$ value. The monetary cost to run an inventory in the Amazon forest was based on the values adopted by IFT for a support technician, amounting to US $\$ 10.76 \mathrm{ha}^{-1}$, and the productivity of $1.36 \mathrm{ha} \mathrm{h}^{-1}$ (Holmes et al. 2002).

The best treatments, in which the calculated sampling error (E\%) was $\leq 15 \%$, were selected for comparison. To compare the best treatments, an analysis of variance (ANOVA) was carried out in a triple factorial design $[2 \times 4 \times 11$, (two levels of sampling procedure, four levels of sampling intensity and eleven levels of plot size], with 30 replications and $\mathrm{E} \%$ as a factor response. The assumptions of homogeneity of variances and normality were met when tested, with significance of $5 \%$ on both Bartlett's test and Lilliefors test, based on the modified Kolmogorov-Smirnov test. When rejecting the $\mathrm{H}_{\mathrm{o}}$ of equal treatments, we used Tukey's test (Zar 1999) to compare which treatments were statistically different at a significance level of $5 \%$. The analyses were performed in R 3.0.2 (R Development Core Team 2015).

\section{Results}

The average tree density of the 18 ha study area was 154 host trees $\mathrm{ha}^{-1}$, with a mean $( \pm \mathrm{SE})$ density of $3.25( \pm 2.74)$ vine roots host $^{-1}$. In general, for all treatments tested, the average number of observed titica vines per tree host varied from 2.55 $( \pm 1.68)$ to $4.25( \pm 3.11)$. The estimate of average production for the random process was $570( \pm 14.99)$ vine roots $\mathrm{ha}^{-1}$, with an interval ranging from 538 to 606 vine roots ha ${ }^{-1}$, while that of the systematic process was $595( \pm 29.52)$ vine roots $\mathrm{ha}^{-1}$, with a range varying between 540 and 681 vine roots ha ${ }^{-1}$ (Fig. 1). The number found in the reference inventory was $500( \pm 215)$ vine roots ha ${ }^{-1}$.

The treatments with plot sizes of $40 \mathrm{~m} \times 15 \mathrm{~m}$ and $30 \mathrm{~m} \times 30 \mathrm{~m}$ for random and systematic sampling, respectively, had the lowest production estimates, on average. Treatments with plots of $6 \mathrm{~m} \times 150 \mathrm{~m}$ and $8 \mathrm{~m} \times 150 \mathrm{~m}$, random and systematic, respectively, had the highest production estimates, on average (Fig. 1). However, both sampling procedures resulted in production values that were very close to the estimate obtained in the area.

The sampling errors obtained by the process of random sampling ranged from 13.22 to $37.93 \%$, with an average value of $22.20 \%( \pm 8.25)$. The systematic process presented more sample error variability, with a range of 10.71 to $46.61 \%$ and an average of $21.50 \%( \pm 10.03)$ (Table 2$)$. In the

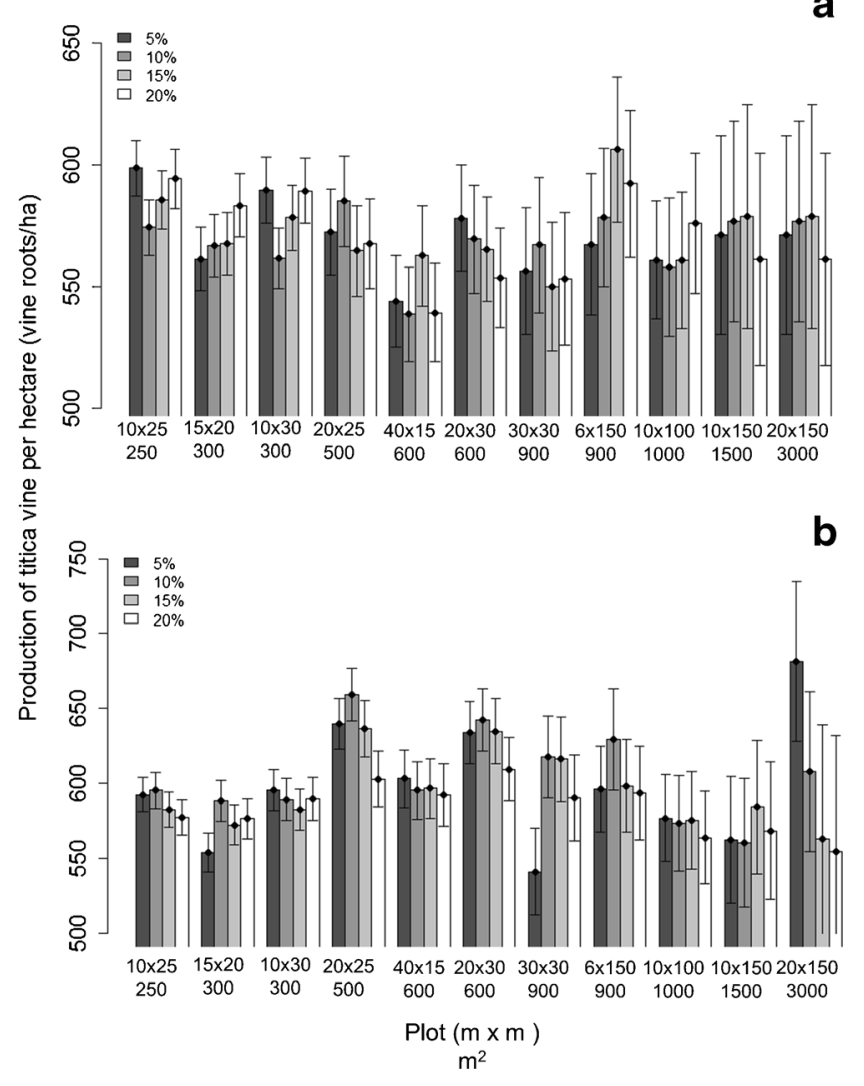

Fig. 1 Estimated production of titica vine (Heteropsis spp.) per hectare for different sampling strategies in relation to the sampling intensity and size of plot $(\mathrm{m} \times \mathrm{m})$ tested. Vertical bars represent the standard deviation among the replications. a Random process. b Systematic process

systematic process, a greater number of treatments showed values lower than the allowed sampling error maximum (Table 2). Higher values of E\% were associated with the sampling intensity of $5 \%$ for both sampling procedures.

As shown in Table 2, of the two sampling procedures assessed, sampling errors were greater than the maximum assumed for transect-type plots. In general, the square and rectangular plots were associated with lower $\mathrm{E} \%$ values; further detail in the production estimate was reached when sampling intensity was magnified from 5 to $20 \%$ (Table 2). In accordance with the criterion of selection of the best treatments on the basis of the lowest values of $\mathrm{E} \%$, of the 88 total treatments evaluated in this study, only 15 were selected as the best (Table 2).

Considering only the 15 treatments with sample error response less than $15 \%$, there was a significant difference between the random and systematic procedures $(\mathrm{GL}=1, F=431.32$, $p=2 \times 10^{-16}$ ), between sample intensities of 15 and $20 \%$, and or among the seven types of plots $(\mathrm{GL}=6, F=302.88$, $p=2 \times 10^{-16}$ ). On the other hand, it was found that there was no significant interaction between the three factors tested ( $\mathrm{GL}=6, F=1.19, p=0.27$ ), indicating that the sampling processes, sample intensities, and types of plots acted independently 
Table 2 Sampling error (E\%) according to the different sampling procedures for each plot size and sampling intensity tested

\begin{tabular}{|c|c|c|c|c|c|c|c|c|c|c|c|c|}
\hline \multirow{2}{*}{$\begin{array}{l}\text { Process } \\
\text { sampling }\end{array}$} & \multirow{2}{*}{$\begin{array}{l}\text { Sampling } \\
\text { intensity (\%) }\end{array}$} & \multicolumn{11}{|c|}{ Plot $(\mathrm{m} \times \mathrm{m}) /$ area $\left(\mathrm{m}^{2}\right)$} \\
\hline & & $\begin{array}{l}10 \times 25 \\
250\end{array}$ & $\begin{array}{l}15 \times 20 \\
300\end{array}$ & $\begin{array}{l}10 \times 30 \\
300\end{array}$ & $\begin{array}{l}20 \times 25 \\
500\end{array}$ & $\begin{array}{l}40 \times 15 \\
600\end{array}$ & $\begin{array}{l}20 \times 30 \\
600\end{array}$ & $\begin{array}{l}30 \times 30 \\
900\end{array}$ & $\begin{array}{l}6 \times 150 \\
900\end{array}$ & $\begin{array}{l}10 \times 100 \\
1000\end{array}$ & $\begin{array}{l}10 \times 150 \\
1500\end{array}$ & $\begin{array}{l}20 \times 150 \\
3000\end{array}$ \\
\hline \multirow[t]{4}{*}{ Random } & 5 & 24.889 & 27.780 & 27.629 & 28.272 & 29.221 & 31.79 & 32.636 & 35.115 & 27.963 & 37.931 & 37.931 \\
\hline & 10 & 18.309 & 19.265 & 18.638 & 20.772 & 21.616 & 23.421 & 24.06 & 21.28 & 23.513 & 27.236 & 27.236 \\
\hline & 15 & 15.439 & 15.609 & 16.05 & 17.687 & 18.022 & 18.504 & 19.161 & 19.619 & 18.809 & 24.658 & 24.658 \\
\hline & 20 & 13.222 & 13.443 & 13.708 & 15.113 & 15.924 & 15.589 & 16.937 & 17.652 & 16.432 & 20.847 & 20.847 \\
\hline \multirow[t]{4}{*}{ Systematic } & 5 & 20.184 & 24.034 & 24.47 & 24.303 & 26.887 & 28.147 & 31.099 & 37.303 & 34.347 & 46.011 & 23.260 \\
\hline & 10 & 15.881 & 17.433 & 17.538 & 16.117 & 18.044 & 18.583 & 20.453 & 29.998 & 27.994 & 31.526 & 20.297 \\
\hline & 15 & 12.435 & 13.876 & 14.368 & 14.951 & 14.58 & 16.101 & 16.708 & 23.009 & 23.71 & 26.153 & 33.919 \\
\hline & 20 & 10.708 & 11.980 & 12.530 & 12.346 & 12.501 & 13.605 & 14.394 & 20.256 & 19.313 & 24.195 & 31.431 \\
\hline
\end{tabular}

Note: italicized font indicates sampling error less than or equal to the maximum error allowed for the study (15\%)

on the sampling error. As shown in Fig. 2, within the group of 15 treatments selected, four statistically similar groups, in relation to the maximum sampling error allowed, could be formed.

The estimate of average production per hectare for the 15 treatments with sampling error $\leq 15 \%$ was 582 vine roots ha ${ }^{-1}$. The treatment with plot dimensions of $15 \mathrm{~m} \times 20 \mathrm{~m}$ was associated with the lowest estimated vine root density ( 572 vine roots $\mathrm{ha}^{-1}$ ), and the plot with dimensions of $20 \mathrm{~m} \times 25 \mathrm{~m}$ was associated with the largest value of estimated vine root density (636 vine roots $\mathrm{ha}^{-1}$ ), both for the systematic process and intensity of $15 \%$. In general, the average production estimate for the treatments selected as best was within the range of the production estimate found for the reference inventory, guaranteeing an accurate estimate (Fig. 1).

With respect to efficiency ( $\mathrm{e} \%$ ), the treatment considered the baseline was the systematic process, with an intensity of

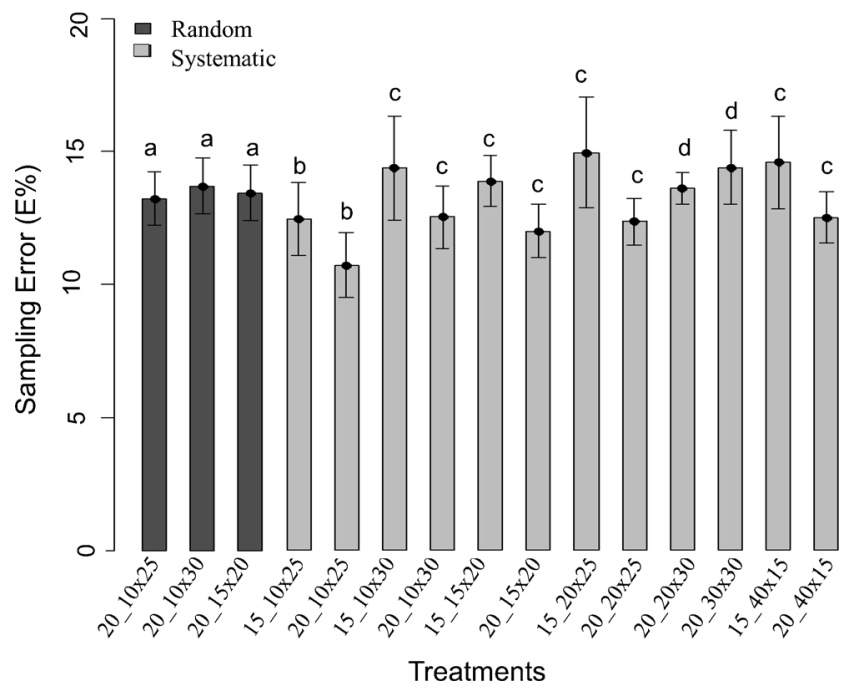

Fig. 2 Average sampling error (E\%) of titica vine between replications, by sampling procedure, intensity, and type of plots for the 15 treatments selected as the best. Vertical bars represent the standard deviation among the replications. Note: 15 and 20 correspond to intensities of 15 and $20 \%$, respectively. Different letters indicate significant differences
$20 \%$ and plot dimensions of $10 \mathrm{~m} \times 25 \mathrm{~m}$, due to the lower sampling error (E\%) value (Figs. 2 and 3). From this treatment basis, the best treatments were selected based on the value of efficiency above $50 \%$ (Fig. 3). These four treatments differed with respect to $\mathrm{E} \%$, being aggregated into three distinct groups, as shown in Fig. 2.

\section{Discussion}

Different sampling procedures, plot sizes and shapes, and sampling intensities were compared and evaluated in this study to propose an efficient sampling strategy to inventory titica vines in Amazon rainforest region at lowest cost. Thus, we suggest a methodology for sampling of vines for evaluating areas of management interest for species productivity. We

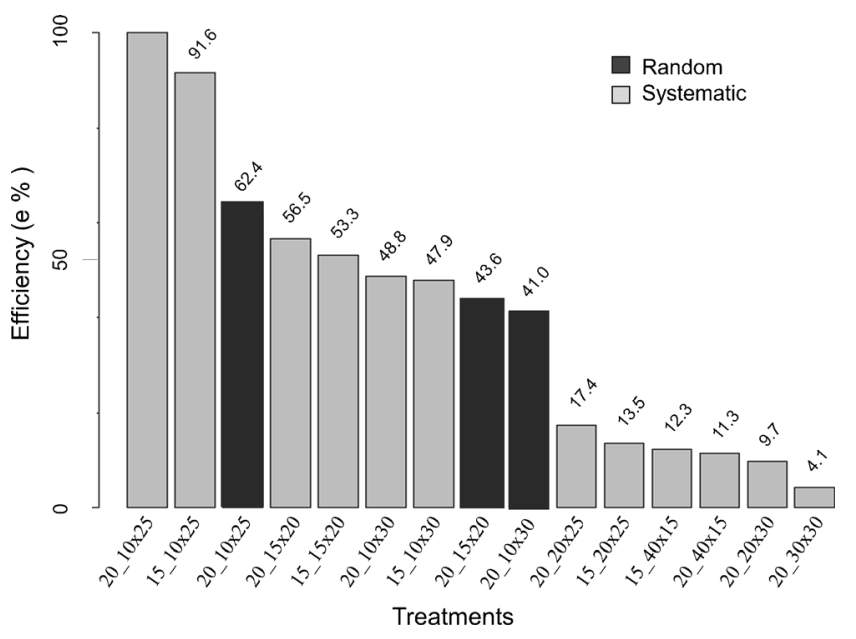

Fig. 3 Relative efficiency $(\mathrm{e} \%)$ in relation to the most efficient treatment (intensity of $20 \%$ sample unit $10 \mathrm{~m} \times 25 \mathrm{~m}$ ), according to the different sampling procedures in each sampling intensity and shape of the plot $(\mathrm{m} \times \mathrm{m})$ tested, for the 15 treatments selected according to the maximum sampling error admitted (E\%). Note: 15 and 20 correspond to intensities of 15 and $20 \%$, respectively 
define the sampling strategy that is most efficient in terms of time and resources.

\subsection{Random and systematic process}

For the 88 treatments analyzed, the average estimates of the titica vine roots per area were low $\left(583 \pm 26\right.$ vine roots ha $\left.{ }^{-1}\right)$ compared to those of other studies of the same species in the Amazon region; others have found densities ranging from 544 to 1748 vine roots ha $^{-1}$ (Fadima 2003; Hoffman 1997; Plowden et al. 2003). Even though we have only 12 reference plots, our inventoried area (18 ha) has the largest sample area when compared to other studies, such as Fadima (2003), Hoffman (1997), and Plowden et al. (2003).

Additionally, the genus Heteropsis does not present any specific parameter or "preference" for host trees to climb (Balcázar-Vargas et al. 2015; Bentes-Gama et al. 2013; Knab-Vispo et al. 2003), differences in estimated production may be influenced by environmental conditions (Plowden et al. 2003), including the forest composition, structure, climate, and soil type of the area. Moreover, among the stands selected for allocation of reference inventory plots, the latest timber exploitation by low impact technique happened in 2008, which may have altered the spatial distribution of host trees, thereby altering titica vine density.

Both random and systematic sampling showed a tendency to overestimate production compared to the reference inventory. However, the production estimate obtained in both the sampling processes was within the expected range $(500 \pm 154$ vine roots $\mathrm{ha}^{-1}$ ).

Heteropsis spp. has a random spatial distribution (BalcázarVargas et al. 2015; Durigan and Castilho 2004; Ferreira and Bentes-Gama 2004), due to the randomly search by the vine for a host. In the case where the vine standing up to a host tree was detected randomly, accurate estimates of production were obtainable under both random and systematic processes (Husch et al. 1972; Zar 1999). The sampling method to be selected should consider the size and shape of the sampling units. As the process is influenced by the spatial distribution of the species to be investigated (Zar 1999).

In comparison to random sampling, the systematic sampling allows the sampling units to be distributed uniformly over the area (Soares et al. 2009) and can best represent the population to be studied. In addition, it can capture gradients and highlight profiles within a population related to the slope of the terrain, soil fertility, and other factors. Systematic sampling has been shown to be less biased and less costly for allocation and reassessment sampling (Krebs 1999), so it is not surprising that systematic sampling process was more efficient, with sampling error less than or equal $15 \%$ in 12 treatments, compared to only three treatments for the random process (Fig. 2).
In general, the sampling error was lower in the systematic process than the random process, due to the lower standard error of the mean and the higher average value of roots per plot. The predominance of low standard error of the mean in the systematic process is mainly explained by the lower variability of production among the sample plots.

The random sampling process captured more variability due to gaps, which are discontinuities or openings in the canopy of the forest. This finding supports the fact that the systematic process produces better results of sampling error $(\mathrm{E} \%)$ and relative efficiency $(\mathrm{e} \%)$ than the random process, although we detected overestimation of titica vine production in some situations (Fig. 1), probably because the distribution of the titica vine may have been fragmented by timber management activities and rocky outcrops in the study area (personal observation).

\subsection{Size and shape of sample unit}

Our findings demonstrate that plot size and shape are critical sampling parameters for titica vine inventory. The size and shape of sample plots should be considered a key parameter for titica vine surveys due mainly to their influence on the accuracy of production estimates (i.e., over or underestimation) and sampling error (E\%). In general, we found that sampling error increased as the area of the sample unit increased, even as the sampling intensity decreased. In the systematic process, rectangular and square plots with areas ranging from 500 to $900 \mathrm{~m}^{2}$ overestimated the titica vine production values by more than $20 \%$ compared to the reference inventory.

Sample units with areas larger than $500 \mathrm{~m}^{2}$ (rectangular/ square and transect shape) may be sampling more titica vine hosts on average, but we also noted a concomitant rise in the standard deviation when the sample unit area increased from 250 to $3000 \mathrm{~m}^{2}$ (Fig. 1). Transects plots uniformly distributed over the area may have captured more discontinuities than the rectangular plots, resulting in greater variability between sampling units and higher standard error leading to higher sampling error.

We noticed the opposite in the random process, where the production estimation per area was not greater than $20 \%$ in relation the reference inventory for all treatments tested (Fig. 1). The differences among random process treatments were that the standard deviation values and sample unit areas increased concomitantly, which provided an unbiased estimate of production.

Statistically, production estimates were significantly different between sampling process (random and systematics) and reference inventory, but were not significantly different between random and systematic process $\left(F=7.49, p<110^{-4}\right)$. Even the production estimates were not significantly different between sampling processes; the minimum difference in 
estimated production and its accuracy is reflected in monetary terms to the forest manager.

In addition, plot size and shape may effectively result in production estimates with low sampling error (E\%) and high efficiency (e\%) independently of the sampling procedure. We observed good production estimates with low $\mathrm{E} \%$ using the rectangular plot of $10 \times 25 \mathrm{~m}\left(250 \mathrm{~m}^{2}\right)$ in both systematic and random process (Table 2 and Fig. 1). The same size plot was used by Plowden et al. (2003) in a random sampling process.

This type of plot may have better captured the pattern and distribution of titica vine host abundance, produced lower sample variances, may therefore be more immune to the ill effects of forest discontinuity, and less likely to be biased by edge effects-as can occur in transect plots. From a statistical point of view, plots of small dimensions with more replications offer greater benefits for forest inventory (Phillips et al. 2003), and for titica vine as well. Moreover, large plots may cause loss of efficiency due to the tendency of species to form associations or aggregations (Zar 1999). The choice of plot size in titica vine inventory therefore requires a sensitive balance among several competing factors: (1) the need to minimize edge effects from forest discontinuities and sampling error, (2) the need to maximize the precision and accuracy of the variable of interest (e.g., production of titica vine roots), and (3) the need to minimize measurement effort and travel time.

\subsection{Sampling intensity}

All treatments varied in accuracy yet provided consistent estimates of production of titica vine roots. As the sampling intensity increased the sample error decreased. A smaller number of sample units and higher values of Student " $t$ " may have induced a higher standard error, which is reflected by the sampling error. Silva et al. (2007) and Ubialli et al. (2009), for example, showed that sampling intensities equal to or less than $10 \%$ proved to be sufficient to obtain accurate estimates of wood production. In our study, we noticed that the estimated production of titica vine per hectare associated with lower $\mathrm{E} \%$ was related to treatments with sample intensities of 15 and $20 \%$. However, the optimal sampling intensity varies with the total size of the area of interest, and also we emphasize that in this study area sampling area ranging from 2.7 to 4 ha provided the most accurate titica vine production estimates by hectare, with values near the reference inventory.

\section{Conclusion}

In this study, we developed and tested methods for titica vine inventory in a Brazilian tropical rainforest. This is the first study to evaluate a sampling method for a non-timber forest product type vine in tropical forest. The definition of a sample scheme is an important step in management plan development; therefore, based on the results found herein, we conclude that the best method for accurate estimates of production of titica vine in a Brazilian Amazon rainforest typology with a sampling error below $15 \%$ is a systematic sampling system, with intensities between 15 and $20 \%$ and with plot sizes of $250 \mathrm{~m}^{2}(10 \mathrm{~m} \times 25 \mathrm{~m})$ to $300 \mathrm{~m}^{2}(15 \mathrm{~m} \times 20 \mathrm{~m})$, or a random sampling system with a sampling intensity of $20 \%$ and plot size of $10 \times 25 \mathrm{~m}\left(250 \mathrm{~m}^{2}\right)$. Even though we did not consider the direct cost, the framework presented herein can serve as a useful methodology, and the result will ultimately support further study and management of titica vine as well as other vine species. We hope that the promising methods for titica vine inventory presented in this study will stimulate further research and applications, not just for inventorying and monitoring titica vine, but also for other non-timber forest products.

Acknowledgments This study was part of the $\mathrm{PhD}$ research of the first author. We give thanks for the support of the fieldwork provided by the Tropical Forest Institute (IFT), in particular Iran Pires, Newton Dutra, Paulo Bittencourt, Zenilton Borba, Alfredo, Miúdo, and Filho. We thank Rachel and Benjamin Bright for their helpful suggestions on an earlier draft of the manuscript.

\section{Compliance with ethical standards}

Funding This study was funded by the Foundation for the State of São Paulo (FAPESP), Process No 2010/16525-7.

\section{References}

Alvares CA, Stape JL, Sentelhas PC, Gonçalves JLM, Sparovek G (2013) Köppen's climate classification map is Brazil. Meteorol Z 22:711728. doi:10.1127/0941-2948/2013/0507

Amapá (2015) Resolução COEMA No. 13, 30/07/2009. http://www. sema.ap.gov.br/download/coema/resolucoes/13.pdf. Accessed 26 June 2015.

Balcázar-Vargas MP, van Andel TR, Westers P, Zuidema PA (2015) What drives the vital rates of secondary hemiepiphytes? A first assessment for three species of Heteropsis (Araceae) in the Colombian Amazon. J Trop Ecol 31:251-265. doi:10.1017/S0266467415000115

Belcher B, Schreckenberg VK (2007) Commercialisation of nontimber forest products: a reality check. Dev Policy Rev 25:355-377. doi:10.1111/j.1467-7679.2007.00374.x

Bentes-Gama MM, Vieira AH, Rocha RB (2013) Ecological features of titica vine (Heteropsis flexuosa (Kunth) GS Bunting) in Rondônia State, Northwest Brazilian Amazon. An Acad Bras Cienc 85:11171125. doi:10.1590/S0001-37652013000300015

Boot RGA (1997) Extraction of non-timber forest products from tropical forests. Does diversity come at a price? Neth J Agric Sci 45:439-450

Bruzinga JS, Oliveira MLR, Nogueira GS, Pereira IM, Leite HG, Machado ELM (2014) Sampling methods to quantify the Pequi Caryocar brasiliense Cambess adults. Ciênc Rural 44:1341-1347. doi:10.1590/0103-8478cr20130239

Cavalcanti FJB, Machado AS, Osokawa RT, Cunha US (2011) Comparison of the estimated values by sampling in the characterization of the structure of a forest area in the Amazon with the 
information recorded in forest census. Revista Árvore 35:10611068. doi:10.1590/S0100-67622011000600012

D'Eça-Neves FF, Morellato LPC (2004) Métodos de amostragem e avaliação utilizados em estudos fenológicos de florestas tropicais. Act Bot Bras 18:99-108. doi:10.1590/S0102-33062004000100009

Development Core Team R (2015) R: A language and environment for statistical computing. R Foundation for Statistical Computing, Vienna, http://www.R-project.org/. Accessed 22 January 2015

Druszcz JP, Nakajima NY, Péllico Netto S, Yoshitani Junior M (2010) Comparação entre os métodos de amostragem de Bitterlich e de área fixa com parcela circular em plantação de Pinus taeda. Floresta 40: 739-754. doi:10.5380/rf.v40i4.20326

Durigan CC, Castilho CV (2004) O extrativismo de cipós (Heteropsis spp., Araceae) no Parque Nacional do Jaú. In: Borges SH, Iwanaga S, Durigan CC, Pinheiro MR (eds) Janelas para a biodiversidade no Parque Nacional do Jaú: uma estratégia para o estudo da biodiversidade na Amazônia. Fundação Vitória Amazônica, Manaus, pp 231-245

Evans TD, Viengkham OV (2001) Inventory time-cost and statistical power: a case study of a Lao rattan. For Ecol Manag 150:313322. doi:10.1016/S0378-1127(00)00589-2

Fadima MG (2003) Fibers from the Forest: Mestizo, Afro-Ecuadorian and Chachi Ethnobotany of Piquigua (Heteropsis ecuadorensis, Araceae) and Mocora (Astrocaryum standleyanum, Arecaceae) in Northwestern Ecuador. Dissertation, University of Texas at Austin

Ferreira MGR, Bentes-Gama MM (2004) Ecologia e formas de aproveitamento econômico do cipó-titica (Heteropsis flexuosa (H.B.K.) G.S. Bunting). Embrapa Rondônia, Porto Velho. https:// www.infoteca.cnptia.embrapa.br/infoteca/bitstream/doc/859448/1/ doc95cipotitica.pdf. Accessed 31 October 2015

Fick TA (2011) Amostragem para inventário florestal em sistemas silvipastoris. Rev Árvore 35:1033-1038. doi:10.1590/S0100-6762 2011000600009

Gama JRV, Botelho AS, Bentes-Gama MM, Scolforo JRS (2001) Tamanho de parcela e suficiência amostral para estudo da regeneração natural em floresta de várzea na Amazônia. Rev Cerne 7:1-11, http://www.redalyc.org/articulo.oa?id=74470201. Accessed 01 May 2015

Hoffman B (1997) The biology and use of nibbi Heteropsis flexuosa (Araceae): the source of an aerial root fiber product in Guyana. Thesis, Florida International University

Holmes TP, Blate GM, Zweede JC, Pereira R Jr, Barreto P, Boltz F, Bauch $R$ (2002) Financial and ecological indicators of reduced impact logging performance in the eastern Amazon. For Ecol Manag 163:93110. doi:10.1016/S0378-1127(01)00530-8

Husch B, Miller CI, Beers TW (1972) Forest mensuration, 2nd edn. The Ronald Press, New York

IBGE (2001) Mapa de Solos do Brasil - Escala 1:5.000.000. Rio de Janeiro: IBGE. ftp://geoftp.ibge.gov.br/mapas_tematicos/geologia/ unidades_federacao/pa_geologia.pdf. Accessed 20 april 2016

IBGE (2004) Mapa de Biomas do Brasil, primeira aproximação. IBGE, Rio de Janeiro, http://www.ibge.gov.br. Accessed 25 June 2015

Kleinn C, Laamanen R, Malla SB (1996) Integrating the assessment of non-wood forest products into the forest inventory of a large area: experiences from Nepal. In: Leakey RRB, Temu AB, Melnyk M, Vantomme P (eds) Domestication and commercialization of nontimber forest products in agroforestry systems.Proceedings of an
International Conference held in Nairobi. FAO, Rome, pp 23-31, http://www.fao.org/3/a-w3735e.pdf. Accessed 31 January 2016

Knab-Vispo C, Hoffmann B, Moermond T, Vispo C (2003) Ecological observations on Heteropsis spp. (Araceae) in Southern Venezuela. Econ Bot 57:345-353. doi:10.1663/0013-0001(2003)057[0345: EOOHSA]2.0.CO;2

Krebs CJ (1999) Ecological methodology, 2nd edn. Addison Wesley Longman, Menlo Park

Oliveira J, Potiguara RCV, Lobato LCB (2006) Fibras vegetais utilizadas na pesca artesanal na microrregião do Salgado. Pará Bol Mus Para Emílio Goeldi Ciênc hum 1:113-127. doi:10.1590/S1981-8122 2006000200009

Péllico Netto S, Brena DA (1997) Inventário florestal. UFPR, Curitiba

Phillips OL, Martinez RV, Vargas PN, Monteagudo AL, Zans MEC, Sanchez WG, Cruz AP, Timana M, Yli-Halla M, Rose S (2003) Efficient plot-based floristic assessment of tropical forests. J Trop Ecol 19:629-645. doi:10.1017/S0266467403006035

Piqué M, Berta Obon SC, Santiago S (2011) Comparison of relascope and fixed-radius plots is the estimation of forest stand variables in northeast Spain: an inventory simulation approach. Eur J For Res 130:851-859. doi:10.1007/s10342-010-0477-x

Plowden C, Uhl C, Oliveira FA (2003) The ecology and harvest potential of titica vine roots (Heteropsis flexuosa: Araceae) in the Eastern Brazilian Amazon. For Ecol Manag 182:59-73. doi:10.1016/ S0378-1127(03)00030-6

Scipioni MC, Alves CG, Durigan CC, Morais MLCS (2012) Exploração e manejo do cipó-titica (Heteropsis spp.). Ambiência 8:139-153. doi:10.5777/ambiencia

Shanley P, Medina G (2005) Fruit trees and useful plants in Amazonian life CIFOR, Embrapa Amazônia Oriental, Imazon, Belém, http://www. fao.org/docrep/015/i2360e/i2360e.pdf. Accessed 21 January 2015

Silva GF, Xavier AC, Rodrigues FL, Peternelli LA (2007) Análise da influência de diferentes tamanhos e composições de amostras no ajuste de uma relação hipsométrica para Eucalyptus grandis. Rev Árvore 31:685-694. doi:10.1590/S0100-67622007000400013

Soares ML, Mayo SJ, Croat TB, Gribel R (2009) Two new species and a new combination in Amazonian Heteropsis (Araceae). Kew Bull 64: 263-270. doi:10.1007/s12225-009-9113-7

Stockdale MC, Wright HL (1996) Rattan inventory: determining plot shape and size. In: Edwards DS, Booth WE, Choy SC (eds) Tropical rainforest research - current issues. Kluwer Academic Publishers, The Netherlands, pp 523-533

Tonini H (2013) Amostragem para a estimativa de produção de sementes de castanheira-do-brasil em floresta nativa. Pesq Agropec Bras 48: 519-527. doi:10.1590/S0100-204X2013000500008

Ubialli JA, Figueiredo Filho A, Machado AS, Arce JE (2009) Comparação de métodos e processos de amostragem para estudos fitossociológicos em uma floresta ecotonal na região norte matogrossense. Floresta 39:511-523. doi:10.1590/S0044-5967 2009000200009

Wong JLG, Thornber K, Baker N (2000) Non-wood forest products 13: resource assessment of non-wood forest products. Experience and biometric principles. FAO, Rome, http://www.fao.org/docrep/018/ y1457e/y1457e.pdf. Accessed 31 January 2016

y Paz MCG, Balslev H, Valencia R (1995) Useful lianas of the SionaSecoya Indians from Amazonian Ecuador. Econ Bot 49:269-275. doi:10.1007/BF02862346

Zar JH (1999) Biostatistical analysis, 4th edn. Prentice-Hal, New Jersey 